\title{
OBSERVATIONS UPON THE STATUS OF CORPORA- TIONS IN CUBA SINCE 1898
}

Gordon IRELAND

The lawyer trained in the English language and the common law who looks through a civil law book is usually both perplexed and annoyed to find no appearance at all as a heading of "Corporations" in translation, and very scant, or even also wholly missing, treatment of the foreign equivalent for "Company." $\mathrm{He}$ thinks he knows that Corporations such as his law creates and permits do in fact exist in countries where the civil law rules; but he cannot find out much about them for himself, and he seldom gets a very good understanding of their status or operation from the civilian Doctor to whom he applies; usually by correspondence, for specific information. The difficulty is real, frequently of serious import in these days of increasing worldcircling by one's corporate clients, and only partially resolvable as long as each consultant thinks and speaks in terms of his own body of law, for the legal systems have been nominally further apart on this topic perhaps than on any other continuously through the centuries of conscious articulate development of each system. In Cuba, however, the American lawyer has a peculiarly advantageous laboratory for the study of Corporations under a civil law régime, if the observations can be duly translated into English terms and groups; for not only are American corporations taking a constantly greater part in the business of the sister Republic, with corresponding effect upon both legislation and decisions, but in addition, American-trained lawmakers, with more than transient power, have been imposed by fate upon the Spanish civil law system twice within the last three decades. The results combine to make this topic capable, if properly presented, of intelligent approach by lawyers of the United States who come into contact with Cuban law. 


\section{HisToRy.}

The law of Cuba today is based upon the Spanish Codes, ${ }^{1}$ the laws made by Military Orders or Decrees of the American Governors (Jan. I, I899-May 20, I902; Sept. 29, 1906Jan. 28, I g09) and the legislation of the Presidents and Congress of the Republic (May 20, 1902-Sept. 28, 1906; Jan. 29, I909 to date), as interpreted and applied by the Supreme Court of Cuba ( 1899 to date). ${ }^{2}$ The Codes are in great part derived from and are in the form of the Napoleonic Codes of France; but from the source of those, in turn, the Roman law of Justinian and Gaius, the Spanish jurists in some points claim direct and not always secondary derivation. It will be recalled; as to our present topic, that the classic Roman law knew several types

${ }^{1}$ For a superficial enumeration of the principal provisions, see Peter $\mathrm{J}$. Hamilton, The Spanish Civil Code, (IgI8) 3I HARv. L. REv. I089-II03. An excellent working summary of its subject is Guerra Everett, Trading under the Lazes of $C_{u b a}$, Trade Information Bulletin No. 343, U. S. Dept. of Commerce (April, 1925). One of the best short statements in Spanish is in IV FELTPE SANCHEz Romín, Derecho Crvn, (Madrid I899) chap. 19, 519-547. A treatise covering the modern Spanish law is R. GAY DE MONTELLA \& J. CoDERCH NIELLA, SocIEDADES ANónImAs (Barcelona 192r). Both these last are, of course, in civil law style; expositions wholly, without reference to cases or other authority.

'The judgments of the Tribunal Supremo, the highest court of appeal for all of Cuba, are not to be found in any single collection. Those in other than criminal cases are published, and hereinafter referred to, as follows:

\begin{tabular}{|c|c|c|}
\hline $1899-1907$ & Official Series, Vols. I-40 & (Vol. No.) Sup. (page) \\
\hline 1908 & Gaceta Oficial, daily & $\begin{array}{l}\text { (7 or 8) G. O. (I, Jan.- } \\
\text { June ; II, July-Dec.; }\end{array}$ \\
\hline I909 and 1910 & $\begin{array}{l}\text { Unofficial collection by } \\
\text { Colegio de Abogados }\end{array}$ & (9 or 10) Jur. (page) \\
\hline $\begin{array}{l}\text { I9II and Igr2 } \\
\text { (through Sept.) }\end{array}$ & Gaceta Oficial, daily & $\begin{array}{l}\text { (ro, II or I2) G. O. (I, } \\
\text { Jan.-June; II, July- } \\
\text { Dec.; page) }\end{array}$ \\
\hline I9I2 (Oct.)-I925 & $\begin{array}{l}\text { Jurisprudencia a I Dia; } \\
\text { private monthly review. } \\
\text { (The kinds of decisions } \\
\text { are gathered and paged } \\
\text { separately; Contencioso- } \\
\text { Administrativo, A; } \\
\text { Civil, C; Hipotecaria, } \\
\text { H; and Inconstitucion- } \\
\text { alidad, U). }\end{array}$ & $\begin{array}{l}\text { (r2, r3-25) Jur. (A. C. } \\
\text { H. or U; page) }\end{array}$ \\
\hline 1926-date & Gaceta Oficial, daily & $\begin{array}{l}24 \text { G. O. (I, II or III, for } \\
\text { Jan., Feb. or March; } \\
\text { page) }\end{array}$ \\
\hline
\end{tabular}


of units other than natural men, which could have rights and as a group were said to have corpus. ${ }^{3}$ The most important private units of this sort appear to have.been devoted to particular cults, guilds with various objects and ecclesiastical groups ; ${ }^{4}$ and while distinguished as "universitates," had some attributes not unlike the partnership (societas). Their law was not apparently of sufficient general interest to call for special distinction or notice, while that of the partnership, the almost exclusive method of carrying on the commerce of the world, developed and grew both clear and powerful, with a continuity that survived the changing mastery of Europe. When Napoleon's jurisconsults prepared their Codes for the regulation of the commerce the French flag was to protect, they were familiar with the civil law of partnership, and devoted to it one title of forty-two articles, ${ }^{5}$ while the subject "Universities" nowhere appears in its original sense. The Spanish Civil Code, following the form of the French model very closely, at this point, also devotes a single title in its last book, and forty-four articles ${ }^{6}$ to Partnership. In both systems, a Code of Commerce ${ }^{7}$ supplies many regulatory details for mercantile transactions of various sorts and between several possible contracting parties, distinguishing kinds of "Societies" without special attention to the dealings of corporations as such, or mention of the name. The basic rules of law are, however, to be derived from the Civil Code; and when the Commercial Code is silent, or the situation does not

3 The Roman law of corporations is touched upon in various senses by eminent authorities. See, for example, Samuel Williston, Law of Business Corporations, (1888) 2 HARv. L. REv. IO6, I18, I2I, I23, I64; Arthur W. Machen, Jr., Corporate Personality, (I9II) 24 HARv. L. Rev. 255, 36I, 363; Roscoe Pound, Sociological Jurisprudence, (IgII) 24 HARV. L. REv. 603-604; Judson A. Crane, The Uniform Partnership Act, (1915) 28 HaRv. L. REv. 763, 765; Richard F. Cleveland, Status in Common Law, (1925) 38 HARv. L. REv. I088; Lobingier, Inter-American N. I. L., (1926) I2 A. B. A. J. 243.

'Buckiand, Roman Law (I92I) I75-I8I, 290, 5 II. Gatus, Institutiones (WHITTUCK, 4th ed. I904) II8-I2I, 245. Societé.

${ }^{5}$ Code CiviL (1803) Book III, Title IX, Art. 1832-1873, Contrats de

'Cónrgo CIvir (1889) Book IV, Title VIII, Art. I665-I708, De la Sociedad

'Spanish Código de Comercio (1885) Book II, Title I, Art. II6-238, De las Compañias Mercantiles. 
come under it, the question must be settled according to the general Code and its jurisprudence.

While Spanish legislation does not contain the specific provision to be found in the French $^{8}$ and some other systems, that the courts shall interpret each case from the very language of the Code itself, and expressly without regard to previous court decisions, even the highest, Cuba has that civil law theory of jurisprudence in its tradition of centuries, only slightly affected as yet by observation of the Anglo-American reverence for precedent. All Cuban decisions are supposed to be merely interpretation of the Codes or other legislative language, and to be in no sense controlled by previous opinions. Its own decisions are occasionally referred to by the court in its judgments; those of the Supreme Court of Spain, rarely; of France, once or twice; and of other jurisdictions, practically never. Such a reference, when it occurs, is offered always as illustrative of the position or view the Supreme Court of Cuba has now taken and expounded, not in any degree as furnishing, beforehand, compulsion or even inclination to that view; it is applause, not prompting.

One of the permitted and most common grounds for -appeal from a lower decision in Cuba, as in Spain, is "infraction of the law." Where the appellant's counsel relies on decisions rather than Code articles to support this assignment, he must cite two cases exactly in point decided by the Supreme Courts of Spain before 1899 or of Cuba since. One case alone is said ${ }^{9}$ to establish no doctrine which the lower decision now objected to can infringe. It will be noted that precedents thus have as yet in Cuba only procedural and no substantive effect, whatever may be the present or future tendency, from the propinquity of American ideas, and the gradual assimilation of procedure in

"Code Crvil, Art. 5: "reglementaire" and jurisprudence thereon.

- This doctrine is first stated in Macicior c. Serrano (1905), 28 Sup. 20 at $3 \mathrm{I}$, and is brought down through numerous decisions to M. J. Brandenstein \& Co. c. Livi (I925), 25 Jur. C. 545 and Fernandez c. Rodriguez (I925), 25 Jur. C. 567. The doctrine appears to be peculiar to Cuba: see Empresa Maritima, S. A., c. Insular Engineering Co. (I925), 25 Jur. C. 403 and Note. A single decision of the Cuban Supreme Court is, however, binding upon all Cuban Courts of lower jurisdiction: Echevarria c. Rouco et al. (rgog), 8 G. O. I 3874 . 
the engrafted alien fields of unconstitutionality, habeas corpus, workmen's compensation and one or two other common law juridical notions.

\section{Classification.}

Not all contracts or dealings which the North American is perhaps accustomed to jumble in the loose group which he calls "business" constitute acts of commerce within the special provisions of the Commercial Code. ${ }^{10}$ The distinction rests primarily upon trading in things; persons or other entities who dedicate themselves habitually to it; and the direct exchange of money for present or future tangible goods or other money. Thus the Commercial Code regulates stores, shops and markets; banks, produce and stock exchanges; warehouses; railroads, land transport and shipping; brokers, factors, and commission merchants; non-mutual insurance; mercantile loans, credits, negotiable and other paper; and bankruptcy; while it leaves to the Civil Code the rules of agency, surety, mortgage, contracts for services, professional or otherwise, single sales and quasi-contracts. In general, the corporation which manufactures something, large or small, which it wants to sell in Cuba, would find its business there classed as "commercial" and itself "mercantile"; while the corporation which does a contracting business, development, construction, dredging or exploitation, will probably not be under the Commercial. Code, but governed by the Civil Code or special laws or decrees. Many questions of frequent occurrence can be answered with greater certainty if the dealing is of a commercial nature ${ }^{11}$ than if the Civil Code has to be interpreted for the case. A local lawyer should be consulted, preferably of course in advance, as to any particular operation whose commercial character seems'ambiguous. 'The mercantile nature of a Society is proved, when it becomes an issue in Court, by certi-

${ }^{20}$ The distinction between "civil" and "mercantile" was not to be found in the Siete Partidas or earlier legislation, but appeared as did "Sociedades Anónimas" in the Commercial Code of 1829. Cf. Martorell c. Araras (1919), ig Jur. C. 3I.

${ }^{11}$ Guillardin c. Benitez (192I), 2I Jur. C. 4 I. 
ficate of the notary who has protocolized the original agreement of association, quoting such clauses as are appropriate from the document before him. ${ }^{12}$

Societies coming under the Commercial Code are treated alike, as to the result of their dealings with third persons; but there are distinguished, as in France, ${ }^{13}$ three kinds, ${ }^{14}$ which differ in their constitution and internal relations between their members: (I) the "colectiva" or regular partnership, in which all the partners, under a common name and management, share alike, though in any agreed proportion, the same rights and obligations; (2) the "comanditaria" or special partnership, in which one or more contribute capital to a common fund for ventures managed exclusively by others, under the common name; and ( 3 ) the "anónima," in which the associates contribute fixed equal portions to the common capital, evidenced by shares or otherwise, and entrust its management to agents or administrators who represent the Society, under some name appropriate to its object or business.

The ordinary common lav corporation thus becomes the "Compañia anónima" of the Commercial Code, or the "Sociedad anónima" of the less exact though common lay usage. . The Civil Code nowhere speaks of Companies but always of "Sociedades" (Partnerships), while the Commercial Code of four years earlier used "Compañias" throughout; so that as the law stands "Compañia" should strictly be applied to such "Sociedades" only as have a determined mercantile or commercial character; and those that have not should not be called "Compañias" in any form. Neither business, legislation nor even the Courts themselves are careful about this distinction, however, in practice; and for any user of a common law vocabulary it is especially important to note that "Compañia" is not the equiva-

12 Ramos et al. c. Gómez (I906), 31 Sup. 436.

${ }^{23}$ Jules Valery, The World War, etc., (I918) 31 Harv. L. Rev. 998-1010; Charles G. Loeb, The Legal Status of American Corporations in France, reviewed by Pierre Lepaulle, (I923) 36 HARv. L. REv. 769-770; (1924) 37 HaRv. L. Rev. 6II, Note.

"Commercial Code, Art. i22. A new fourth class, "Sociedades Limitadas," to be composed of from two to ten members, is created in a new law which passed the Senate on Feb. 8th, I926. 
lent of Corporation as distinguished from Partnership, but when technically used distinguishes commercial from non-commercial Societies, and that to either of those classes a Corporation may belong. The law we must examine will of course follow the same divisions; and although we direct our real interest to "Sociedades anónimas," points that settle true corporation questions may be found anywhere in the law of Societies; and often the court's decision will apply precisely to the form "colectiva" or "comanditaria," which the American lawyer would consider partnerships and not corporations at all. Where "Corporaciones" is actually used in Spanish law, ${ }^{15}$ it is either a recent borrowing, without definition or explanation, from foreign law, or is used ${ }^{16}$ precisely in the correct historical sense, to refer to ecclesiastical and municipal bodies. These groups we exclude from the present consideration, as calling for special treatment, as they do in many respects at common law; and, except so far as they come under the general law, we exclude also those classes of corporations engaged in businesses tinged with a public interest, and regulated, as in the United States, by specific provisions. Such are banks, railroads, tramways, warehouses, and telephone, telegraph, gas and electric companies. We may use the common term "members" to designate partners or stockholders in Societies, without limitation or attempted distinction.

Whichever American view of the personality of partnerships be favored or prevalent at the moment, it must be borne in mind throughout the present discussion that the civil law knows no such conflict at any point. The Society, of any sort, has juridical personality from the moment it is created by contract between its members; ${ }^{17}$ which means simply that it acts as an entity distinct from any of its members; it has its name, funds, property, rights and liabilities, whch last until its exist-

${ }^{25}$ E. g., Crvil Code, Art. 28, 35, 37. EnJurc. Civir, Art. 502.

${ }^{16}$ So, of a Municipality: In re Cia. Conces. de Abasto de Carnes (Igor), 9 Sup. 38; in re Suárez (rgII), to G. O. II 6058; in re Hotel Sevilla (I9I2), II G. O. II 2664; in re Gómez (I9I2), II G. O. II 4504.

${ }^{27}$ Civil Code, Article 35. Commerctal Cone, Article ir6. López c. Cia. Azucarera Naranjal (I922), 22 Jur. C. I97; in re Hermanos Zulueta y Gamiz (I925), 25 Jur. A. 69. 
ence is duly terminated according to law; and when it appears in court as a party it is always represented, as a natural person frequently is, by duly accredited and empowered individuals who speak for it in all things; as to lay matters, by administrator, manager or agent; as to legal matters by Procurador or attorney-at-law. As we shall see, ${ }^{18}$ this representation itself becomes a major topic of the law, by no means peculiar to Societies, and the result is the relegation of all discussion of "personality," so prolific in the common law, to a very minor place in the civil law.

\section{Creation.}

A Society is created by a formal written instrument signed by the parties interested before a notary, and being so formally entered in his books and in the Mercantile Registry as to become technically a "public document"; and endowed with the effect and consequences which such formalities give in the Civil Law system. ${ }^{19}$ If the Society is newly formed under Cuban law, this original contract of the parties themselves, setting forth the terms of their agreement, is the only thing necessary to bring into being the new personality, and in the case of a Sociedad or Compañia Anónima forms directly what the common law attorney calls the charter of the corporation. The recital in this document of the commercial character ${ }^{20}$ or of the kind of Society ${ }^{21}$ being formed is conclusive upon the members, who will not be allowed to give proof of an intention to form one of the other kinds. There is in the Codes and there appears as yet to have been established by the jurisprudence no limitation of any sort as to number, nationality or residence of the members (or incorporators) nor even of the place where this original agreement must be executed. It would almost certainly be defective in material respects if made without civil law advice before an English or American notary (public), and if the Society is to

\footnotetext{
2s See "Agents," infra.

${ }^{20}$ In re Cia. de Gas y Electricidad (19Io), 1o Jur. 472.

${ }^{20}$ Lora c. Centurión (I92I), 21 Jur. C. 3.

${ }^{21}$ Bermúdez c. Soc. Brauet y Cia. (1904), 23 Sup. 923.
} 
be formed under Cuban law, execution of the document even in other civil law countries is attended by a certain amount of risk. All practical reasons dictate the execution of the document in Cuba, those non-residents who cannot conveniently be present in person, and all the parties, if necessary, being represented through a carefully drawn power-of-attorney, specially given for the purpose.

The name may be any not unduly like one in use, and must begin or end with "Sociedad Anónima," commonly abbreviated to "S. A." "In use" is construed so literally that a Society expiring by limitation or going into liquidation for insolvency or other reasons may be succeeded and even liquidated ${ }^{22}$ by another with the same ${ }^{23}$ or an almost identical ${ }^{24}$ name, and of the same or a different class $;^{25}$ so that persons without actual notice continuing to trade with the same people at the same location and under a similar name may be and undoubtedly not infrequently are passively deceived as to the actual legal entity with which they are dealing. The duration may be for one or more given ventures or for any specified term of months or years or perpetual; and, if limited by purpose or period, may before its expiration be extended for any further term or made perpetual by another public document. Where the term does not definitely appear in the instrument, it may on suit brought be fixed by the Court, if possible, from any revelant circumstance. ${ }^{26}$

The purpose of obtaining gain and dividing the profits, to which each member contributes something, regardless of other conditions, distinguishes the Society from an agency or hiring on commission, ${ }^{2 \pi}$ and from a social, athletic, political or educational "Centro" or Club. The distinction is important, since either of these other relations will at civil law be brought into being by a public document which in form and in many of its

\footnotetext{
${ }^{2}$ In re Zárraga, Martinez y Cia. (I917), I7 Jur. C. 205.

${ }^{23}$ C. B. Stevens y Cia. c. Query (1913), 13 Jur. C. 341.

${ }^{24}$ M. Phillips c. Pita et al. (r923), 23 Jur. C. 265.

${ }^{25}$ Garcia y Cia. c. Sun Ins. Office of London (I907), 38 Sup. 83I.

${ }^{*}$ Fixed, for example, at the same term as the lease of the premises to be occupied: Rodriguez c. Otero (IgII), II G. O. I 366.

${ }^{2}$ Andrade c. Aguiar (Ig02), I4 Sup. I4.
} 
clauses may closely resemble the agreement for creation of a Society. The object of the Society must be stated in the agreement, and it is often said, as in the common law, that such object must be lawful. There is, however, no general statute or statement of any sort, so far as known, attempting to enumerate any list even of classes of prohibited objects, and the prevalent liberal state of opinion in the Republic ${ }^{28}$ indicates that a court would not find illegal many contracts the objects of which would be thought repugnant to public manners or morals in the United States. For example, although the law prohibits and punishes ${ }^{28}$ conspiring to alter the price of labor or merchandise, and especially "articles of food or other things of prime necessity," an association of ice companies and dealers and breweries formed to control the price of ice was allowed to. sue, without the defense of illegality of object being raised, a company which had agreed to join but afterwards refused, ${ }^{30}$ and the suit succeeded to the extent that the defendant was ordered to live up to its agreement, though an award of damages to the plaintiffs was refused on the ground that the admitted lower price was not proved to have been due solely to the defendant's acts. In the one case found in which an illegal object was discernible from the outset, "solely to cheat and defraud persons that contracted commercially with it," the court said that although the group was perhaps a "mercantile entity," it certainly was not such a

${ }^{23}$ The Lottery is a State monopoly, protected by penal laws. Apparatus gambling and horse racing (largely for tourist trade), beer gardens, theatres, professional base-ball, and all public spectacles and amusements are the subject of concessions or special licenses which may be issued in proper cases to Societies as readily as to individuals. Religion is disestablished and free; and sects of any belief, or even professing none, may form Societies at will, so long as they do not disturb public order. Organized or professional charity, cruelty and antivice societies are perfectly legal and free to operate if they wish, as does the W. C. T. U., in a field where they are practically unknown, the Government taking care of poverty and vice when either becomes too obtrusive. Antigovernmental or violent groups do not, any more than in other parts of the world, advertise the full extent of their objects in their public documents; and can be adequately dealt with under the penal laws, or their leaders under the well understood Ley de Fuga, when their actions outstrip their pretensions. Business frauds likewise do not ordinarily develop until subsequent to the original drawing up of the contract of association, and are vigorously dealt with under effective punitive statutes by prosecuting officials urged on by protective and watchful commercial associations.

2 PeNAL Code, Art. 567, 569.

${ }^{30}$ Zaldo, Carvajal y Cia. et al. c. Cia Cervecera Int'l. (I918), I8 Jur. C. I81. 
"mercantile society" as would protect its individual members from prosecution personally under certain sections of the penal law. ${ }^{31}$ If the object is to conduct a bank, insurance business, railroad, tramway or omnibus line, ferry, gas or electric supply plant, slaughter-house, dairy or warehouse, certain special requirements as to responsibility must be met.

The capital may be put in as money, property; services or skill, with practically no restrictions as to valuation, provided the subscriptions are not totally fictitious ${ }^{32}$ and that the members are not deceived in any respect among one another. A number of details which at common law are usually left to the bylaws are customarily, and in some cases, necessarily, included in this first instrument of association; especially particulars as to boards, persons and officers to be entrusted with general or divided management; salaries and accounts for them, and other members; manner and business of meetings; and the by-laws themselves. The members in a "Sociedad Anónima" are liable for Society debts only to the extent of the capital it is recited they or their predecessors in holding had agreed to or did contribute. $^{33}$

This instrument when signed before the Notary is entered in his private registry ("protocolized") and he issues certified copies which are taken to the Commerce Department, where fees are paid and one copy filed, and to the Mercantile Registry of the District of the Society's home office, or property and main operations, where another copy is entered. This constitutes the complete legalization of the Society, and establishes its full right to do business in Cuba. Amendments to the original agreement, ${ }^{34}$ change in kinds, amount or isues of stock or shares, bond issues, amendments to the by-laws which may affect the rights of third persons directly or by change of authorizations of the persons representing the Society, extensions or renewals and in general all things which materially affect the Society's

" Estado c. Prins (I9Io), Io G. O. I 5426.

" In re Cia. de los Puertos de Cuba (I9I5), I5 Jur. A. 213.

${ }^{2}$ In re Ferrocarril de Nuevitas, etc. (I90I), 9 Sup. 104. La Invencible, S. A. c. Matadero de Luyanó (I9I2), II G. O. II 2818 .

"Touzet c. Bustillo, San Miguel y Cia. (r922), 22 Jur. C. 53. 
existence have also to be thus registered. Such Registry has in most respects the quality of a common law public record, to the extent of charging all the world with notice of the facts there appearing; as for example, the period stated for the duration of a Society. ${ }^{35}$

Failure of any Society actually engaged in commerce, as discussed above, ${ }^{36}$ to register its original agreement or subsequent material changes in the Mercantile Registry of its District, besides giving the State the right to move in court to annul the document, ${ }^{37}$ leaves such Society, as it does any individual merchant, unable to obtain the inscription of any public document concerning its business, ${ }^{38}$ to bring suit ${ }^{38}$ or to do other acts requiring legal recognition; but cannot be pleaded as a total or partial defense to suits against it on documents or contracts made by it as a Society. ${ }^{40}$ An agreement which should have been registered, but was not, may be registered at any time ' (prior, at least, to its expiration, if limited), and such late registration has the effect of curing the previous lack of a legal requisite, without which the contract was not non-existent, but merely incapable of being enforced. ${ }^{41}$ The registration requirement may be said then, perhaps, to go to the remedy rather than to the right; but to leave the provision with any teeth at all, it is of course true that rights of third persons already accrued cannot be altered by subsequent registration. The terms of any original agreement not registered are not to prejudice any third person; who can, however, take advantage of any terms he learns of favorable to himself ; and the entire instrument is valid in all respects as between the parties to it. ${ }^{42}$ If there has been an oral

${ }^{25}$ Garcia y Cia. c. Sun Ins. Office of London (1907), 38 Sup. 83 I.

"See "Classification," supra.

${ }^{27}$ Estado c. El Globo, S. A. (I925), 23 G. O. V II642.

${ }^{28}$ In re Atlantic Fruit Co. (I92I), 2I Jur. H. I3.

${ }^{20}$ A. J. Lascelles y Cia. c. Oakdale Mfg. Co. (I908), 8 G. O. I 1614 A foreign company not established in commerce in Cuba need not register its charter before suing: Alfred Meyer y Cia. c. Moeller et al. (19I5), 15 Jur. C. 269 .

${ }^{\circ}$ Erviti Loidi y Cia. c. Courtillier (1902), I4 Sup. 309; Suárez c. Lazcano (1906), 31 Sup. 302 ; Rodriguez c. Otero et al. (19ro), 10 Jur. 359.

"La Invencible, S. A., c. Matadero de Luyanó (I9I2), II G. O. II 2818.

- Commercial Code, Art. 24. 
or memorandum agreement acted upon and business commenced, without the formal written instrument, any member may by suit require the others to agree upon and execute the necessary document to set forth formally the full agreement. ${ }^{43}$

A Society not originally mercantile in nature has to be registered when it wants to transfer real property in Cuba, ${ }^{44}$ and if not previously located by its place of business, the appropriate registry is that for the District in which such real property, or the Society's first real property, is situated. ${ }^{45}$

Fees are payable on registration, and must be settled in full, including the charges of the Commerce Department, if not previously entered and paid there, before the registration is complete and has full legal effect. The normal property transfer tax must be paid upon changing property to subsidiary Societies ${ }^{46}$ or to a new Society which is the result of a merger, ${ }^{47}$ even when paid for by a bond issue up to the full value of the property, ${ }^{48}$ as no provable identity of interest or control is allowed to overcome the actual difference of juridical personality. No intent to make a direct cash profit by the sale is necessary, to make the transfer taxable. ${ }^{47}$ A stock issue will be taxed at its face value regardless of the discount at which it is put out, $^{49}$ or the real value of the property received for it. ${ }^{50}$ There is no taxable transfer when the property of a dissolving Society passes to its liquidators. ${ }^{51}$ The annual income tax, although by no means so complicated as that of the United States, for corporations, involves consideration of a number of business and accounting details which cannot be gone into here. It may, however, be noted in passing that interest paid on a mortgage

\footnotetext{
is Rodriguez c. Otero (19II), Ir G. O. I 366.

"Lateulade c. Lateulade (I9I4), I4 Jur. C. I35. In re Argüelles, López et al. (I9I7), I7 Jur. H: 35. Galdo c. Rosillo (I9I7), I7 Jur. C. 34I.

${ }^{45}$ So, for an extension of the duration of the Society: In re Martinez y Cia. (1905), 26 Sup. 398.

"In re Banco del Comercio (I902), i3 Sup. 6ro.

${ }^{4}$ In re Cia. Litográfica de la Fabana (I908), 8 G. O. I I806.

${ }^{4}$ Ibid. And cf. in re Saetia Sugar Co. (1916), I6 Jur. A. I7.

- In re Ciego de Avila Cia. Azucarera (I918), I8 Jur. A. II9.

"Ir re Soc. Garcia \& Traba (I9II), Io G. O. I 5869.

${ }^{51}$ In re Zárraga y Cia. (I9I6), I6 Jur. A. 27.
} 
bond issue ${ }^{52}$ or on the unamortized portion of an installment mortgage $^{53}$ is allowed to be deducted as part of the running expenses of the Society. ${ }^{54}$ Dividends received on shares owned in other Societies are taxable as income, even though the money has already paid one tax as income of the distributing Society. ${ }^{55}$

At the commencement of a-law suit by a Society, there must be filed with the first paper in court, besides fully authenticated powers to the representative and attorney to act, a certificate from the Mercantile Register that the Society is duly entered; and without this the action may be dismissed, on objection by the defendant. When there is such a certificate, the existence of the plaintiff Society may still be denied by the defendant, unless he has by any judicial act in the same proceeding already admitted its existence $;^{56}$ and if denied it has to be affirmatively proved by the plaintiff from the original protocolized documents and entries. ${ }^{57}$

\section{ForEIGN CORPORATIONS.}

A Society (corporation or other entity) already existing in the United States or elsewhere may become legally authorized to do a commercial business in Cuba while retaining its home charter, principal office, officials and volume of business in any proportion it may desire. The process is, broadly, merely doing with the original home charter what has been described as necessary for Cuban incorporation; but the details of the process are numerous and vital. Copies in triplicate of the complete charter, and all amendments on file to date must be obtained, duly authenticated by the Secretary of the issuing State; copies of the bylaws, correct to date, lists of directors and executive officers with the votes or certificates of election by which they took.

In re Cia. Eléctrica, etc. de Santiago (1913), I3 Jur. A. 5.

"In re Trust Co. of Cuba (1909), 9 -Jur. 398.

4he Tax Administration may reject expenses claimed but in its opinion not proved, or not proper: in re Cia. Azucarera Caobillas, S. A. (I92I), 21 Jur. A. 35.

${ }^{s 5}$ In re Ferrocarriles Unidos, etc. (1918), 18 Jur. A. I.

stewart \& Co., Itd., c. Central Nueva Paz (1910), ro Jur. 80. Cf. "Agents," infra.

"A. J. Lascelles y Cia. c. Oakdale Mfg. Co. (Ig08), 8 G. O. I I6I4. 
office, and copies of the resolutions of the directors' and stockholders' meetings authorizing the doing of business in Cuba, appointment of an agent there, and designation of specified persons to take the necessary steps therefor, all signed by the secretary of the company, and a power of attorney by the president to the specified agent, must be acknowledged by the secretary and president before a local notary public, whose certificate must show that he knows those officers to be such; the county clerk's or Secretary of State's certificate to the notary must be attached; the whole legalized by the nearest Cuban Consul or the Minister in Washington, and then transmitted by the corporation to the Cuban State Department in Havana, where a certificate as to the authority of the Consul or Minister will be attached, all previous parts officially translated into Spanish and the three complete sets delivered to the corporation's agent in Cuba, to be protocolized before a notary there. They must be certified as tax exempt by the Treasury Department, or the required tax paid and then two copies duly entered in the Commerce Department and the appropriate Mercantile Registry, as in the case of Cuban Societies. The third complete copy remains in the corporation's main Cuban office, subject to examination on call by the authorities at any time. The matters of fees, and the relative advantages of Cuban incorporation, a special American corporation to handle Cuban business or the establishment in Cuba of branch offices of an existing American corporation involve many considerations not appropriate here; but it should be remarked that the amount of taxes payable depends in part upon the capital of the business in Cuba. In the case of foreign corporations this may be assumed to be the whole capital unless care be taken in the resolutions for the establishment of Cuban branches to assign a definite portion of the total capital of the corporations to the Cuban business. The value of capital, or property paid for by issuance of shares, remaining altogether outside of Cuba is not to be included in the calculations for taxes upon registering. ${ }^{58}$

ss In re Soc. Galbán y Cia. (I90I), 8 Sup. 504. 
At and after the point of presentation of the documents to the Commerce Department and Mercantile Registry for entry, the situation of the branch of a foreign corporation in Cuba is equal in all respects before the Cuban law to the situation of a Cuban Society, as hereinbefore described. What has been said as to members, duration, purpose, object, capital, amendments and effects of failure to be registered, after the protocolization with the Cuban Notary, applies equally to the foreign corporation and the Cuban Society. The name is that originally established by the home charter, the corporation now domesticated in part in Cuba being the actual foreign entity, and is not required to end in "S. A." nor to be translated into Spanish, the original title being exactly retained wherever it occurs, even in the State Department's official Spanish version of the papers, although a Spanish paraphrase usually appears in parentheses once or twice, chiefly to show the nature of the business to be done, if that is indicated by any part of the English name. It is commonly stated that for registration the authorities must be satisfied that the corporation was legally authorized to do the business set forth in its charter in the State in which it was incorporated; but except as to those facts to which the Cuban Consul will certify ${ }^{50}$ there is no procedure established by which legal proof of anything may be made to either the Commerce Department or the Mercantile Register; nor has any case been found where a registration was rejected on the ground of home illegality.

The Cuban Constitution provides ${ }^{60}$ that foreigners resident in Cuba shall be equal to Cubans as to (I) protection of person and property, (2) Bill of Rights, (3) certain civil rights, (4) obligation to obey the law, (5) submission to the courts and (6) obligation to pay taxes. This provision is understood, without jurisprudence as without discussion, to apply to foreign corporations duly registered in Cuba; so that the question of whether or not such corporations are "resident in Cuba" remains of only academic interest. The provision is repeated in the same

\footnotetext{
${ }^{\infty}$ Comarercial Code, Art. 2I, par. 2.

${ }^{\infty}$ Title III, Art. 10.
} 
words in the Civil Code, ${ }^{61}$ while the Commercial Code ${ }^{62}$ expressly permits foreign corporations to do business in Cuba, subject as to their capacity to contract to the laws of their own country, and as to the opening of branches in Cuba, doing business and jurisdiction of the courts, to the laws of Cuba except as otherwise provided by treaty in particular cases. Cuban court jurisdiction is further defined ${ }^{63}$ to include actions by or against foreigners concerning contracts made within or outside of Cuba with Cuban citizens or relating to real or personal property within Cuban territory, and actions between foreigners concerning contracts made or to be performed in Cuba. In one case, however, in which the contract was to be performed in Cuba, the nationality of the individual plaintiff not appearing the court held that it was without jurisdiction, as the defendant company was domiciled in the United States and remained there. ${ }^{64}$ This was perhaps more a recognition of the practical, than insistence upon the literal, effect of the law just stated.

Not every dealing or entering into relations by a foreign corporation with persons in Cuba establishes it there so as to require registration in $\mathrm{Cuba}$ of the corporation before it may bring suit or have the protection of the law to the extent above set forth. The necessity for registration depends not so much upon "doing business," with the common law problems and refinements of that term, as upon the preparation and intention to perform "acts of commerce" in the sense hereinbefore discussed, or to hold itself out to the public for service. The test looks more to the degree to which the corporation itself comes within the territory of the Republic than the frequency or manner of its so doing. Bearing in mind the historical and constant tendency of the civil law to regard an agent as much more "on his own" than does the common law, we may safely conclude that the sending of a solicitor of orders, travelling salesman with or without samples, collector of accounts for remittance home

\footnotetext{
"Art. 27.

- Art. I5. Cf. Aliens Law (Extranjeria), Art. 40.

* Aliens Law, Art. 42, 43.

${ }^{*}$ Cáceres c. Bankers Export Co. (I92I), 21 Jur. C. 299.
} 
without administrative discretion, and procuring of sales contracts, whether considered to be made in Cuba or outside, for goods to be imported, delivered direct to the purchaser and paid for in Cuba, without more will not require the foreign corpo ration to be registered; while opening an office in the name of the corporation, publishing any kind of advertisement or public notice, ${ }^{65}$ giving administrative or executive functions by power of attorney to an agent, arranging for construction or performing services of any kind in Cuba, require previous registration, to keep within the protection of the law, before a single customer has been served or hour's work done. Merely making a contract with Cuban individuals or Societies ${ }^{68}$ or even owning and exploiting lands and mining properties in $\mathrm{Cuba}^{67}$ is not such an act as requires registration in the Mercantile Registry: and when what has been done does not require the foreign corporation to be registered, it may come into the Cuban courts and bring suit upon the contract, still without any requirement of being registered. It is evident then that the objection by a defendant (corresponding to a plea in total abatement), that the plaintiff was not registered, should be successful only when the defendant also shows or the plaintiff assumes that the matter in suit was such an act as legally required the plaintiff to have been registered before entering upon it. ${ }^{68}$

The question of the citizenship, in Cuba, of the foreign corporation duly legalized and registered in Cuba with all necessary formality raises a perplexing problem in private international law ${ }^{69}$ of which no adequate suggestions for a solution can be offered within the limits of the subject in hand. The Platt Amendment ${ }^{70}$ reserves to the United States the right to inter-

es Commerctal Code, Art. 3.

* Alfred Meyer y Cia. c. Moeller et al. (1915), I5 Jur. C. 269.

"MacLoughlin Bros. c. Juraguá Iron Co. (I910), Io Jur. I26. MacLoughlin Bros. c. Badel y Cia. (I9Io), Io Jur. I29.

* Cf. note 39 supra.

- See on this point the Note upon Chauncey v. Chile, (IgoI) I5 HArv. L. REv. 60; and T. Baty, The Rights of Ideas-and of Corporations, (1920) 33 HARV. L. REV. 374 .

${ }^{70}$ Art 3 , of the series of eight additional provisions which the U. S. Senate required to be added to the Constitution of $\mathrm{Cuba}$ as a condition of its approval. 
vene in Cuba for the preservation of her independence and the protection of life, property and personal liberty; so that it is pretty well understood that a third nation pressing beyond diplomatic measures in support of claims of her nationals, such as Societies or Corporations claimed not to be Cuban citizens in spite of registration there, would not be dealing with Cuba, alone: while corporations of the United States able to convince their State Department of the justice of their claims are in specially preferred positions regardless of their technical citizenship rights. And without distinction between nations, the Cuban law generously provides ${ }^{71}$ that the funds of foreigners invested in "Sociedades anónimas" shall not be subject to reprisals in case of war. Before the Cuban courts, the foreign corporation is in all respects the equal of a Cuban Society; and the remaining considerations of the present discussion may be taken as applying to both classes alike.

\section{Promotion.}

The individual who undertakes professionally to gather properties or investors or both, bring them together, arrange incorporation, sell stock or bonds, turn the going concern over to permanent administration, take his pay in notes, stock, bonds, securities or money, and get out, is an intermediary unknown to Spanish law. The Throne preferred to foster such operations by means of grants, privileges and concessions: and illustrations may run from Cortez, who tried to deal in Empires, to the family whose slaughterhouse monopoly General Wood had to put to an end in I899. While the Society remained principally a partnership, with a small number of members and close personal acquaintanceship and confidence, the paid intervention of any stranger was unnecessary; and even with the advent of larger operations, the interesting of necessary further capital was commonly looked after by one or two of the more active or influential members, among their friends, themselves remaining vitally involved in the outcome, to the greater satisfaction and

" Comarercial Code, Art. i6g. 
security of all concerned. When, then, the promoter appears upon the scene, the courts try to recognize in him the likeness of some personality they have known before. He may be acting for himself only, or an agent of some recognized principal of sufficient juridical personality to grant definite powers and undertake fixed responsibility. The promoter who has to come to court to obtain the fulfilment of an obligation he claims to have, must show a complete provable contract, with other parties capable of binding themselves or an entity they duly represented then in existence and having executed formal and sufficient powers of attorney prior to the time of dealing with the plaintiff. His measure of success will be the exact terms of agreement with those with whom he dealt. ${ }^{72}$ While the civil law does know something of quasi-contracts and the doctrine of unjust enrichment, it does not understand them to cover a practical substitution of parties, such as may be involved in the common law doctrine of holding the corporation responsible for ante-charter agreements, under certain conditions; and if the promoter can show no new contract with the Society itself, amounting to a formal novation, by which the first parties were relieved from responsibility to each other, and both he and the original investors accepted the now-existing Society as the new debtor, he will have no remedy against such successor entity, on any ground of implied transfer, understood terms or equitable substitution; and he can do only what he may with such original contract as he has, for what it is still worth. ${ }^{73}$ The mistaken belief of one contractor that the other had power to represent certain principals, in dealing with him for the formation of a Society, has been held to vitiate his consent and permit him to have what is called "rescission," but might perhaps be more exactly termed judicial nullification of the agreement apparently made. ${ }^{74}$ The failure of a member to pay in capital or render services as he has agreed gives the Society, formed and started going by the other members in accordance with the agreement,

"Carreja c. Nazábal et al. (I918), I8 Jur. C. 241 .

${ }^{2}$ Güines Co. c. O'Connor (I908), 8 G. O. I I43I; Armas c. Ferrocarriles Unidos, etc. (I908), 8 G. O. I 4113 .

"Gonzáles c. Barlow (I925), 25 Jur. C. 54I. 
a right to rescind the contract as to the delinquent, have him judicially declared out, and recover from him such damages as can be proved. ${ }^{75}$

Winile the Courts decline to hold defendants liable on contracts in which they are not originally formally bound, ${ }^{76}$ a doctrine analogous to cy-pres, or judicial construction of contracts for nearest possible performance when literal performance has become impossible, is rather more liberal. So, the purchaser of a street railroad concession who agreed to pay the concessionaire a fixed part of the price in shares and bonds of an operating Society to be formed within three months, was required to pay the sum named in cash when no Society had been formed at the end of the specified period. ${ }^{7 r}$

\section{Stock and Dividends.}

Whatever has been duly agreed on between the original members may be put in as capital of the Society, and an agreed portion of the stock, or other evidence of participation in the assets of the joint enterprise, given in exchange therefor. ${ }^{78}$ In the absence of deceit no original member can afterward question the valuation assigned in the public agreement which he has signed; and no later member gets any greater right, ${ }^{70}$ but takes his interest as it may stand when he acquires it, subject to the legal result of all things which have been done affecting the Society before he came in. An interest in the ordinary Society is not transferable by any of the original members during the term of the agreement; but the instrument may expressly permit transfer and in the case of Sociedades Anónimas almost invariably does so. If transfer is provided for, it includes volun-

${ }^{75}$ Fina y Cia. c. Cinca (IgII), II G. O. I 223I.

${ }^{78}$ Crvil Cone, Art. 109r, I257.

"Havana Electric Ry. c. Ceballos (I908), 7 G. O. II 5040.

"A note: Blanco c. Soc. J. Bueno y Cia (1902), I3 Sup. 489. An heir's undivided interest: in re Alturas de la Universidad, S. A. (IgI6), 16 Jur. H. 25. Claims due predecessor: Zárraga, Martinez y Cia. c. Fernández (1917), I7 Jur. C. rgr. A plant: Castillo c. Cia. Anon. La Cienfueguera (I92I), 2I Jur. C. 27 r.

${ }^{7}$ Castillo c. Cia. Anon. La Cienfueguera, ubi supra, dictum. 
tary sale or gift, as well as passing by will, inheritance or intestacy, or execution or other legal taking. If transfer is not contemplated, death of one of the members will leave his "Succession" a passive member until the end of the specified term; and if he was an active manager or administrator the survivors will have to appoint by formal instrument duly registered some new managing representative. A member's interest in profits, or dividends, does not entitle him to anything separately until accounts for a given period have been presented to all, settled and agreed upon; ${ }^{80}$ and neither he nor any successor or assignee can maintain any action for any portion on account until all liabilities for the period have been met, and the balance found and accepted by vote of a majority of the members. ${ }^{81}$ If wrongfully disposed of, stock may be ordered purchased at the market, if possible, and restored in kind. ${ }^{82}$

\section{Management.}

In the internal affairs of the Society, the original agreement and by-laws ${ }^{83}$ so far as they go are supreme, and will be respected and enforced in every possible particular by the Court. So, where the by-laws provided that the Society's monthly balances must be approved by the board of directors before being published as required, ${ }^{84}$ the president could not be ordered, at the suit of a stockholder, to comply with the law and publish balances monthly, until they had been approved by the board of directors. $^{85} \mathrm{~A}$ member may examine the administration and accounts only when and as the by-laws prescribe. ${ }^{86}$ A mortgage

${ }^{80}$ Dominguez c. Rodriguez (1907), 36 Sup. 550; Colsa c. Solana Hermanos (1909), 9 Jur. 333; Reyes c. Gutérrez (I9II), II G. O. I 806; Pérez c. Silvester \& Stern (I912), II G. O. II 2688; Lesassier c. Agustin Fuller Co. (19I2), II G. O. II 7074 .

"Castet c. Diaz (1904), 23 Sup. 669.

- Martinez c. Sigarroa (Ig06), 32 Sup. 403; González c. Fantony (Igrz), II G. O. I 6984 .

* Lodeiro c. Fernández (IgII), II G. O. I 4388.

" Commercial Code, Art. izr.

${ }^{8}$ Garcia c. Ingenio Providencia, S. A. (1902), 14 Sup. 97.

* A resolution, already rescinded, of the board of directors granting a sum "in anticipation of dividends" can be questioned by a stockholder only upon presentation at a stockholders' meeting of an account showing the expenditure. 
given upon vote of the executive committee when the registered by-laws provided that only the members' meeting could authorize a mortgage of the Society's property, will be cancelled of record. ${ }^{87}$ When by the by-laws only meat-dealers may be members of a Society, one not a meat-dealer who has acquired a member's shares may receive the dividends payable on them, but cannot have them cancelled and new ones issued in his own name. ${ }^{88}$ The by-laws will govern exactly the calling and conduct of meetings ${ }^{80}$ and votes' taken therein, ${ }^{80}$ the giving of powers of attorney, ${ }^{91}$ and the bringing of law suits ${ }^{92}$ and appeals. ${ }^{93}$

The managers, even if members, are under the duty of giving proper and reasonable account of their actions to the others. ${ }^{94}$ In case of disputes or difficulties not resolvable by reference to either the original agreement or the by-laws, ${ }^{95}$ the courts are inclined to let the majority opinion control; or, in case of a matter of real importance to the future operation and object of the Society, may order dissolution upon the request even of

Belaunde c. Ingenio Providencia, S. A. (I902), I4 Sup. I27. A subsequent stockholder cannot have rescission of a sale of all the Society's property, duly voted and carried out and the full agreed price received. Gómez v. Internacional Motor Co. (I923), 23 Jur. C. 57.

${ }^{87}$ Central Lugareño c. Franke (1907), 38 Sup. 509.

"Martinez c. Union, etc. de la Habana (Ig09), 9 Jur. II6.

- Christie Brown Co., Ltd. c. Ackriell (I92I), 21 Jur. C. 125.

${ }^{\infty}$ When a required quorum of two-thirds is present, votes passed by a majority are valid: Belaunde c. Ingenio Providencia, S. A., I4 Sup. I14. Amending bylaws: Trapiello c. Cia. Azucarera Hispano-Cubana (I922), 22 Jur. C. 39 . A manager may be removed as such by the Executive Committee of which he is a member, though he cannot be removed as Committeeman: Ortega c. Metropolitana Cia. de Seguros (1924), 24 Jur. C. 359.

"Christie Brown Co., Ltd. c. Ackriell, ubi supra note \&9. Cia Nacional de Pianos y Fonógrafos, S. A. c. Soroa (Ig23), 23 Jur. C. 301.

"A manager who has express power to bring actions may do so on his own judgment, although the charter requires the concurrence of a majority of the members to settle law suits: Alvarez, Valdés y Cia. c. Muñiz (r9r3), I3 Jur. C. IIr. A defendant who objects to a suit on the ground of illegal votes of the plaintiff's directors has the burden of proving the illegality, if it is capable of being alleged at all by such a third party: in re Havana Central R. R. (1924), 24 Jur. A. II5.

${ }^{23}$ When the authorization of the directors is necessary for the bringing of suits, it must be obtained for an appeal: In re Cia. Operativa de Santa Clara (Ig26), 24 G. O. II 4720.

" Puig c. J. F. Berndes y Cia. (I903), I7 Sup. 325.

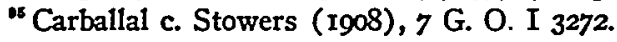


a minority, if substantial, in a proceeding to which all members have been made parties. ${ }^{96} \mathrm{~A}$ Society which succeeds, ${ }^{97}$ whether or not it also expressly undertakes to liquidate, ${ }^{98}$ another, must carry out the former Society's contract ${ }^{89}$ and pay its debts, ${ }^{100}$ and is entitled to enforcement of its contracts receivable. ${ }^{101}$ If, however, there is a separate liquidator who has sold and been paid for the property of the old Society, he and not the new purchaser Society is the proper defendant in a suit on an old obligation; ${ }^{102}$ and the former Society need not be joined. ${ }^{99} \mathrm{~A}$ contingent liability to pay future damages, secured by a recorded mortgage on lands, will follow the lands, and survive reorganizations and mergers which made no mention of it. ${ }^{103}$

\section{Agents.}

The civil more frankly than the common law recognizes the fact of the physical non-existence of the artificial law-begotten entity, and that it must do its actual business in the world by the hands now of one, now of another, natural person capable of real physical acts. But the civil law is not content with the great cloud of implied powers which the common law precipitates around the hardly dry naked charter, and demands instead to be shown the page and line in black and white of the grant of the right to do every specific or possible act, from the highest to the lowest, on behalf of the Society. The president or the executive must be given in a public document, duly signed and certified after votes of the members and the directors, express authority to do all the business of the Society, sign all instruments, make appointments, accept contracts, benefits, liabilities

* Pérez c. Ruiz et al. (1905), 26 Sup. 207.

"Galán c. Cia. Ferrocarriles Unidos, etc. (1912), I2 (13) Jur. C. 149.

${ }^{28}$ M. Phillips c. Pita et al. (1923), 23 Jur. C. 265.

* Pardo c. Reparto Purísima Concepción, S. A. (Igr8), I8 Jur. C. 249.

${ }^{100}$ Golf c. Morris \& Co. (I915), 15 Jur. C. 193.

${ }^{100}$ Gancedo, Toca y Cia. c. Loys (1914), I4 Jur. C. 417.

${ }^{100}$ Meruelo c. Castaño y Cia. (1905), 26 Sup. 82.

${ }^{100}$ Santa Basílica Metropolitana c. Cuban Copper Co. (I912), I2 (13) Jur. C. 23. As to lien of trust mortgage on after acquired property, generally, see Trust Co. of America c. Cuban Sugar Refining Co. (I913), I3 Jur. C. I49 and Victor G. Mendoza Co. c. Cia. Azucarera Central Rey et als. (I922), 22 Jur. H, r, 
and notices, and substitute his powers in any part or degree. General powers, however sweeping and seemingly complete in language, will not do, as American corporations have from time to time found out, to their cost and annoyance; for certain classes of powers, such as to execute deeds or sign or endorse commercial paper, collect money and issue receipts or extend credit, commence and settle or appeal law suits, bid on Government contracts, give security and enter protests against Administrative decisions, make importation invoices, objections and appeals, or register mortgages, patents and trade-marks, have to be specifically bestowed in explicit language.

The extreme technicality of powers of attorney. ${ }^{104}$ has made their creation and attack a vast special study in the law. Probably a quarter of the time of the courts, as certainly a third of the reported decisions, is taken up with determination of the sufficiency or insufficiency of a particular power of attorney under which some act necessary to the plaintiff's cause of action, proof, or bringing suit, has been done, and analysing it meticulously in the light of the objections raised by the defendant. Whether or not influenced by the increasing murmur of the merchants, especially the larger, Spanish, English and American houses, against the unnecessary hazards this refinement of doc-

${ }^{204}$ The power must show the regularity of the call and vote of the Directors' meeting: Christie Brown Co., Ltd. c. Ackriell, ubi supra note 89. A grant of all usual powers to a manager, not specifying guaranty, will enable him to bind the Society as guarantor on his personal note, Gutiérrez c. C. Hempel y Cia. (I913), I3 Jur. C. 4Ir; but not to admit a debt on an account, Pedro Mora, $S$. en C. C. The Victoria Co. (1900), 4 Sup. 24 . A power to use the Society name in all business to protect rights of the Society is sufficient to authorize legal proceedings, Menéndez y Arroyo c. Alonso (I9I0), Io Jur. 40; and a general power for all classes of suits obviates a special one for each action, Boschmonar c. Garcia \& Amador (I923), 23 Jur. C. 237 ; but a power to bring suits does not authorize a proceeding to test the constitutionality of a Presidential Decree, in re Cia. Operativa de Santa Clara (I926), 24 G. O. II 4720 (apparently overruling in re Cuban Central Rys., Ltd. (I908), 7 G. O. II 4392); and a power to put in a tax return does not authorize an appeal against the resulting assessment, in re Mutual Life Ins. Co. of N. Y. (I919), I9 Jur. A. I27; nor can a power not mentioning judicial proceedings authorize a complaint against a Treasury Department decision, in re Southern Dredging Co. (I9I8), I8 Jur. U. 35. Lack of some necessary recitals in the interlocutory step of requiring the maker of a promissory note to admit his signature can be cured by including all proper recitals in the actual first pleading, Rodriguez, Cantera y Cia. c. Pis (I913), I3 Jur. C. I15; but lack of sufficient references in a power to begin a suit cannot be cured by the presentation of any number of documents later, in re G. B. Borsalino fu Lozzaro y Cia. (1918), I8 Jur. A. 165. 
trine has thrown in the way of the deserving plaintiff, bench, bar and even legislators are coming to recognize the situation as an evil and very real threat to the commerce of the country: and it is probable that before long, perhaps even quite soon ${ }^{105}$ a thorough-going piece of constructive legislation will sweep away this misdeveloped and over-emphasized outgrowth of the Roman and Napoleonic idea of mandate, only beginning to be so oppressively distorted in the original Spanish Codes. The one bright spot in the actual situation is the rule, somewhat similar to the common law doctrine of estoppel; that a person may not "go against his own acts," ${ }^{106}$ which we have seen ${ }^{107}$ may help out the proof of existence of a Society, and which here forbids the allegation of lack of power to be heard from a party who has necessarily admitted the power by some act of his own in connection with the same transaction. ${ }^{108}$

From this brief review of the law of the matter, it is obvious that the drawing of a power of attorney to be used in Cuba for however simple appearing an occasion should only be at-

10 A National Codification Commission is now considering the better unification of all the laws of the Republic: and its Section on Mercantile Legisiation, composed of three well-known Havana lawyers, is quite active, meeting weekly and having in preparation a redraft of Title I of Book II (Compañias) of the COMMERCIAL CODE, which may be ready for presentation to the next Congress.

${ }_{106}$ "A nadie es lícito ir contra sus propios actos": Partida 6, Title 8, Law 6. Discussed and applied, among many other cases, in Silvera c. Blanco (rgoo), 4 Sup. 70; Wall. c. González et al. (I9r7), I7 Jur. C. I23; Frias c. Borrell et al. (1918), I8 Jur. C. 85; Garcia c. Padilla (I919), I9 Jur. C. 281. It applies only to the parties in the suit, not to the Court; Lobo c. Blanco (I923), 23 Jur. C. 257 .

${ }^{10}$ Supra note 56.

10 This applies to one who admits dealing, as such, with the PresidentManioca Cia. Agricola Industrial c. León (Ig2I), 2I Jur. C. 2I ; Universal Music \& Commercial Co. c. Morales (1923), 23 Jur. C. 503: Managing AgentFlint y Cia. c. Rivas et al. (1905), 26 Sup. 878; Royal Bank of Canada c. Ibarra (1908), 8 G. O. I 1628; Alvarez y Fernández c. Mariano Quintana y Cia. (1908), 8 G. O. I 283I; Regalado c. León (I9II), II G. O. I I888; Morreau, Spiegelberg y Cia. c. F. Gamba y Cia. (I916), I6 Jur. C. 287; Vaquer, Nos y Cia. c. Mugno et al. (1918), 18 Jur. C. 35I : Liquidator-Hinze y Bedia c. Pérez (I912), II G. O. II 7140; Cia. de Seguros Mannheim, Inc., c. Cia. Naviera de Cuba, S. A. (I923), 23 Jur. C. 409: Procurador-National City Bank c. Vilariño (I923), 23 Jur. C. I7I: or the Society generally-Almiñaque c. Echegoyen y Pérez (I9II), iI G. O. I I63I; Primelles y Varona c. Betancourt y Cia. (rg25), 25 Jur. C. 349 : to the endorser, as to the payee, of a note- $\mathrm{H}$. Upmann - y Cia. c. Pérez (I9I6), I6 Jur. C. 3II ; and against Administrative Departments of the State itself -in re Guantanamo Western R. R. (I9I7), I7 Jur. A. IO9; in re Eléctrica Madrazo, S. A. (I922), 22 Jur. A. 27 ; in re Cia. Nacional de Vinos y Licores (1922), 22 Jur. A. 8I; in re Cuba R. R. (I925), 25 Jur. A. II7. 
tempted by or entrusted to careful attorneys well versed in Cuban law. It is of course Cuban law, and not that of the country where the power is made, that determines the efficacy of the power in Cuba. ${ }^{10 \theta}$

The power of attorney must, to be effective, after legalization by the Cuban Consul and State Department if executed abroad, be entered in the books of some notary of the place where the agent is to act. In the case of a Society. this had better be the same notary who has protocolized the original agreement and by-laws; for acts done under the power will have to be justified from time to time by certified copies obtained from the notary. The power to be used is commonly founded upon clauses of a general nature, defining powers of directors or duties of officers and special votes or resolutions of business, elections or appointments. The notary may certify that he had the duly protocolized original documents before him and knew that the clauses recited were truly contained therein, ${ }^{110}$ that the president, ${ }^{111}$ secretary ${ }^{112}$ or directors ${ }^{118}$ are such or that the term of duration of the Society has been extended, 114 from such votes, certificates and other documents as are legally before him; but may not certify, so as to validate the power in that respect by virtue of his certificate, without further proof, the effect of

${ }^{100}$ Bernard Abel y Cia. c. Rossith (Ig08), 8 G. O. I II4I.

${ }^{110}$ Claudius Asch Sons, Ltd. c. Alonso (Ig02), 12 Sup. I6; in re Cia. Velodromo de la Habana (1909), 9 Jur. 364; Gómez c. Yañez (19ro), ro Jur. 363; in re Zárraga, Martinez y Cia. (1917), I7 Jur. C. 205; Vizoso, Torres y Cia. c. Martinez y Cia. (I921), 21 Jur. C. I2I; in re Atlantic Fruit Co. (I922), 2r Jur. H. 29; in re Swift \& Co. (I922), 22 Jur. A. 6I ; Prendes y Paradela, S. en C. c. Villa (I922), 22 Jur. C. 349; P. Oliva, S. en C. c. Hernández y Cia (1923), 23 Jur. C. II3.

I11 Cia. Colonial Progreso c. González (1916), I6 Jur. C. 261 ; Cia. Comercial de Créditos e Informes c. Alas (rgr8), 18 Jur. C. 463; René Berndes Co. c. Arxer (I924), 24 Jur. C. 449; Guantánamó Land Development Co. c. Hernán$\operatorname{dez}$ (1925), 25 Jur. C. 665.

"1 Stewart \& Co., Ltd. c. Central Nueva Paz (Igro), Io Jur. 80; in re Guantánamo Western R. R. (1917), I7 Jur. A. Iog.

I14 Stewart \& Co., Ltd. c. Central Nueva Paz, ubi supra note II2; Rabone Hermanos y Cia. c. Coto (I9II), II G. O. I 503; Morreau, Spiegelberg y Cia, c. F. Gamba y Cia. (1916), I6 Jur. C. 287; Rickerts' Rice Mills c. Llamas y Ruiz (1925), 25 Jur. C. 313 .

"Horter \& Fair c. Cabaleiro (I912), 12 G. O. I 3641. 
clauses not quoted, ${ }^{115}$ or officers' certificates not protocolized with him, ${ }^{116}$ or the contents of copies of documents protocolized before another notary ${ }^{117}$ or merely sworn to before a foreign notary public $;^{118}$ nor will the statement of a foreign notary as to the effect of laws of his country be accepted. ${ }^{119}$

Inasmuch as the law ${ }^{120}$ permits a natural person to be legally summoned by papers delivered to his servant, a Society may be served with process by delivery to any officer or active member. ${ }^{121}$ When a defendant sued personally and as representative of a Society appears personally only, admissions by him in the suit will not be held binding on the Society. ${ }^{122} \mathrm{~A}$ Society is not liable for damage occurring after its agent has taken necessary precautions against ordinary foreseeable risks. ${ }^{123}$

\section{Dissolution.}

A commercial Society may state in its original agreement that it is for a single enterprise, or a definite number, in whch case it lasts until that adventure or series is completed, and no

${ }^{17 x}$ Alvarez y Fernández c. Mariano Quintana y Cia. (1908), 8 G. O. I 283I ; Martinez y Cia. c. Cueto y Cia. (1915), I5 Jur. C. 129 (two of the seven Judges dissenting); in re Manzanillo Water \& Light Co. (I9I7), I7 Jur. A. I3; in re Bowers Southern Dredging Co. (I9I9), 19 Jur. U. I5; in re Eléctrica Madrazo, S. A. (I92I), 2I Jur. A. 2I, 23; M. Phillips y Cia. c. Larrauri e Inchausti (I923), 23 Jur. C. 329 ; in re Ferrocarriles Unidos, etc. (1924), 24 Jur. A. 85.

${ }^{116}$ In re S. A. Eléctrica Madrazo (1922), 22 Jur. A. 23; Cia. Crédito Com. e Ind., S. A. c. V. Hermosa, S. en C. (1922), 22 Jur. C. I53; in re S. A. Banco de la Libertad (I922), 22 Jur. A. 85; in re Port of Havana Docks Co. (I923), 23 Jur. A. 25; McElroy, Sloan Shoe Co. c. Garcia, Hermanos y Cia. (I923), 23 Jur. C. 235 ; in re Brooks \& Co. (1923), 23 Jur. A. 39; Universal Music \& Commercial Co. c. Morales (I923), 23 Jur. C. 503; Cia. de Crédito C. e I. c. Fernández (1924), 24 Jur. C. 335; in re Cia. Central San Ramón (1924), 24 Jur. U. II ; in re Cuban Portland Cement Co. (1924), 24 Jur. U. I3; Granel y Perera c. Bacon (I925), 25 Jur. C. 557.

.112 In re Manatí Sugar Co. (I92I), 21 Jur. A. 3; Cuban Coal Co. c. O. Cuní y Cia. (I925), 25 Jur. C. 129.

${ }^{113}$ New York \& Java Trading Co. c. Fernández (1908), 7 G. O. II 2924; Stetten y Cia. c. Vázquez, Bravo y Cia. (I909), 9 Jur. 108; in re New York Pharmacal Ass'n. (Ig17), I7 Jur. A. 5.

${ }^{110}$ In re Atlantic Fruit Co. (I92I), 2r Jur. H. 7. Cf. A. J. Lascelles y Cia. c. Oakdale Mfg. Co. (Ig08), 8 G. O. I I6I4.

200 Enjuictamiento Civin, Art. 268.

222 Poujol c. Soc. Sala e Hijos (I902), I2 Sup. 44 I.

222 Alda c. Usabiaga (I905), 26 Sup. 317.

${ }^{22}$ López c. Vuelta Abajo S. S. Co. (I9I5), I5 Jur. C. 33 (Damage by almost unprecedented flood to freight in warehouse). 
longer $;^{124}$ but it is more common to fix a term of three, five, ten or perhaps fifteen years: the same duration for which it might be reasonable in the common law to expect a simple partnership to hold together, with no more than average vicissitudes from human :misunderstandings, ill-temper or death. It is not a ground for dissolution of a Sociedad Anónima that one member claims to have ceased to be such or to have separated from it. ${ }^{125}$

With the vastly greater range of operations of latter days, both capital and industry look for greater permanence of their common interest, and the newer Societies now declare that their existence is to be perpetual, as do most of the charters of the larger foreign entities coming to be registered for commerce in Cuba. If a definite term is fixed, no member may obtain dissolution by Court order before that time; and even voluntary dissolution by agreement of all the members will not be effective to end the Society before the original agreed period unless the new agreement is a public document, and entered with all formalities in the Mercantile Registry. ${ }^{126}$ If one member's signature to the dissolution agreement has been obtained by fraud, he may on discovering it have the instrument set aside, sales under it rescinded, and the Society will continue for its natural term. ${ }^{127}$ On the expiration of the fixed term, no extension is presumed, from any act, tacit agreement or continuation of business by any or all of the members; but if after its life has expired they or any of them want to go on with the Society, those agreeing must sign a new public document complete in all respects as for a new Society, to be duly protocolized and registered; and there then arises for a further term an entity which is new in law, even though it bears the same name and has the same members as the former one. ${ }^{128}$

\footnotetext{
${ }^{21}$ Commercial Code, Art. 218-238. Canova c. Barlow (1906), 32 Sup. 337; Rodriguez c. Ruiz (I923), 23 Jur. C. 95.

${ }^{225}$ Bermúdez c. Soc. Brauet y Cia. (I904), 23 Sup. 923.

${ }^{128}$ Guerra c. Soc. Andino y Pérez (I902), i2 Sup. I49; in re Hijos de Soler (I909), 9 Jur. 386; Soc. Rafecas y Toñarely c. Goizueta (I92I), 22 Jur. C. 39r; in re Brower y Cia. (1924), 24 Jur. C. 459.

${ }^{277}$ Sabido c. Alea et al. (1925), 25 Jur. C. 581. Cf. Andreu c. Coronado et al. (1907), 37 Sup. I.

${ }^{225}$ In re Carbonell, Mestre y Cia. (I905), 26 Sup. 201.
} 
For the expired Society, liquidators or arbitrators named in the original agreement ${ }^{129}$ or, if none was there named or can now serve, those appointed by the Court on application (commonly the general manager or active directors of the former business) ${ }^{130}$ must be permitted a reasonable time to wind up the affairs of the Society, close out its assets, meet all its liabilities, and distribute the final net proceeds as provided in the original contract, by agreement now among all interested parties, or as the Court may direct. When the Society comes to the end of its appointed time wholly solvent, its property and assets ${ }^{131}$ pass to the liquidator, along with its debts, and there is little difficulty, beyond an occasional doubtful clause or unforeseen detail or contingency in the original agreement. If however, the assets of the Society will not meet its liabilities ${ }^{132}$ either at the end of the specified term or mediate in its existence, legal problems are almost certain to arise. The original members remain liable for Society debts as during its continuance until the liquidator's final accounts, duly accepted and entered, show all liabilities met. ${ }^{133}$ Upon application of a member or creditors alleging and proving insolvency, the Court will appoint liquidators whose collecting functions will be much the same as in the case of a solvent termination; but the distribution will be more closely and directly under the detailed instruction of the Court. The liquidator has the right to sue to collect assets ${ }^{134}$ and is the proper party defendant in a suit on an old obligation. In the case of a special deposit, however, somewhat resembling a special trust, the managing members may be joined as defendants with the liquidator. ${ }^{135}$

10 Molina c. Doimingo (I900), 5 Sup. 350; Montero c. Lage (IgII), Io G. O. II 3240; Salgado et al. c. Diaz (I9II), II G. O. I I666.

${ }^{120}$ Rabasa c. Gamba et al. (I923), 23 Jur. C. 469.

${ }^{12 x}$ Gancedo, Toca y Cia. c. Loys (Igr4), I4 Jur. C. 417.

20 Montemar c. Bridat Mont'ros y Cia. (Ig07), 38 Sup. 476.

${ }^{23}$ Riera c. Jané Pascual y Cia. (Igor), 9 Sup. 862.

${ }^{14}$ González c. Valdés (1906), 30 Sup. 684.

${ }^{12}$ Mencia c. Casais (rg12), II G. O. I 7098. 
An attempt such as this to translate the ideas of one system of law into the concepts and even the language of another is certain to be somewhat disappointing on both sides; statements here have lost too much idiom to seem proper to one, and they have not gained enough to be satisfactory to the other. But if these observations make it anywhere easier for Cuban and United States lawyers or clients better to understand each other with mutual respect and advantage, they will have been fully justified. 